\title{
Practice versus Theory: Medieval Materia Medica according to the Cairo Genizah
}

\author{
EFRAIM LEV and ZOHAR AMAR*
}

\section{Introduction}

Much information on medicine and the use of materia medica in the medieval period exists, but it is mainly based on the vast medical literature of that period both in the East and the West. Such books composed in the Arab world cover various subjects: medical theories and doctrines, the maintenance of good health (regimen sanitatis) ${ }^{1}$ or preventive medicine, different diseases and ailments, and qualities of medicinal substances, ${ }^{2}$ pharmacopoeias listing remedies and how to make them, ${ }^{3}$ and materia medica-medicinal substances, their different names and medical uses. ${ }^{4}$

Most of these books were written by qualified and learned physicians and pharmacists, are well organized, and were meant for teaching as well as references for theory and

(C) Efraim Lev and Zohar Amar 2007

* Efraim Lev, PhD, Department of Eretz Israel Studies and School of Public Health, University of Haifa, Haifa, Israel.

Zohar Amar, PhD, Department of Land of Israel Studies and Archeology, Bar-Ilan University, RamatGan, Israel.

This article is dedicated to the late Dr Haskell D Isaacs, a physician and scholar of the history of medicine, who laid the foundation for the research of history of medicine at the Cambridge University Genizah Collection. This research would not have taken place without a generous grant from St John's College, Cambridge, which hosted Efraim Lev as an Overseas Visiting Scholar (2003-2004). The authors would like to express their gratitude for the helpful remarks and suggestions of the three anonymous reviewers, and their deepest thanks to Dr Leigh Chipman, Hebrew University, Israel, for her helpful comments. Special thanks to our colleagues at the Taylor-Schechter Genizah Research Unit at Cambridge University Library, who shared with Efraim Lev their enormous knowledge and experience and supported both authors with helpful remarks: Prof. Stefan Reif, Shulie Reif, Dr Avihai Shivtiel, Dr Friedrich Niessen, Dr Ben Outhwaite, Dr Rebecca Jefferson, Ellis Weinberger, and Sara Sykes. The authors would like to thank the Syndics of Cambridge University Library for permission to publish the Cairo Genizah fragments presented in this article.

\author{
${ }^{1}$ Moshe Ben Maimon (Maimonides), Regimen \\ sanitatis, ed. Süssmann Muntner, Jerusalem, Mossad \\ Harav Kook, 1957; see also edition published in Basel \\ and New York by S Karger, \\ 1966; Ibn Rushd (Averroes), Kitāb al-Kullīyāt, \\ Madrid, Instituto General Franco, 1939 \\ (in Arabic). \\ ${ }^{2}$ Ibn Sīnā (Avicenna), Kitāb al-Qānūn fì al-țibb, \\ Cairo, Bulaq, 1877 (in Arabic); Moshe Ben Maimon \\ (Maimonides), The medical aphorisms of Moses \\ Maimonides, trans. and ed. Fred Rosner and \\ Süssmann Muntner, New York, Yeshiva \\ University Press, 1970. \\ ${ }^{3}$ Martin Levey (ed.), The medical formulary or, \\ Aqrābādhìn of al-Kind̄, Madison, University of \\ Wisconsin Press, 1966; Abū al-Munā al-Kūhīn \\ al-Ațtāar, Minhāj al-dukkān, Cairo, Bulaq, 1940 \\ (in Arabic); Sābūr ibn Sahl, Dispensatorium \\ parvum $=$ al-Aqrābādhīn al-şaghìr, ed. Oliver Kahl, \\ Leiden and New York, Brill, 1994. \\ ${ }^{4}$ Ibn al-Bayțār, Kitāb al-Jāmi 'li-mufradāt \\ al-adwiya wa-al-Aghdhiyah, Cairo, Bulaq, 1874 \\ (in Arabic); Hakim M Said and R E Elahie (eds), \\ àl-Biruni's book on pharmacy and materia medica, \\ 2 vols, Karachi, Hamdard Academy, 1973; \\ M Meyerhof and G P Sobhy (ed. and trans.), \\ The abridged version of "The book of simple \\ drugs", of Ahmad Ibn Muhammad al-Ghäfiqī by \\ Gregorius Abu'l-Farag (Barhebraeus), 4 vols, \\ Cairo, El-Ettemad, 1932-1940.
}




\section{Efraim Lev and Zohar Amar}

practice. ${ }^{5}$ Each author presents the optimal materia medica that should be used (to the best of his extensive knowledge) out of a very large inventory of medicinal substances from all over the Old World.

Little in-depth research seems to have been conducted with the aim of exploring what may have taken place in medieval medical practice in the East. ${ }^{6}$ However, an exception lies in the recent studies of both Graeco-Roman and original Islamic records of medical case histories, namely those written by al-Rāzī (d. 930) in his Kitāb al-Hīw $\bar{\imath}{ }^{7}$ Each physician used the medical knowledge he acquired from his teachers and the medical literature of his time; however, many of the books had been written centuries earlier, often in other parts of the world, and were later translated and copied many times in different geographical locations. ${ }^{8}$ Other books were written by court physicians, commissioned by the local ruler, especially in the Ayyubid period. ${ }^{9}$ Authors of such theoretical books were never limited in choosing the materia medica: for example, Maimonides counselled the sultan al-Afdal (d. 1225) to supply the court pharmacy with the best substances possible. ${ }^{10}$ In contrast, practitioners who had to treat people from the lower socio-economic strata had to prescribe formulas based on the substances they knew and could rely on, and which were available in the vicinity and were stocked by pharmacists. Even then, the availability of the substances was not guaranteed, and sometimes practitioners had to prescribe a substitute formula based on the less expensive and tried and trusted substances at hand. ${ }^{11}$ In reality, the practical inventory of materia medica was thus smaller than the theoretical inventory, which was based upon the books that physicians had in their possession. It was only logical that some medicines and medicinal substances were used more often than others, according to price, availability, practitioners' choices, and even local medical trends.

The main goal of this study was to learn about the practical medicinal uses of various substances by the members of the Jewish community of Cairo as a reflection of the Mediterranean Arab world as a whole. We were able to do this thanks to the Cairo Jewish community's unique habit, based on religious law, of gathering all written documents and keeping them in the attic of their synagogue. These are the Genizah collections, whose survival is also linked to the dry climate of Old Cairo, which contributed much to the preservation of the fragments for more than a thousand years.

The Genizah collections, especially the Taylor-Schechter Collection at Cambridge University Library, which include, inter alia, various medical documents, provide a golden

\footnotetext{
${ }^{5}$ See, for example, Ben Maimon, op. cit., note 2 above.

${ }^{6}$ John M Riddle, 'Theory and practice in medieval medicine', Viator, 1974, 5: 157-84.

${ }^{7}$ Cristina Alvarez-Millán, 'Graeco-Roman case histories and their influence on medieval Islamic clinical accounts', Soc. Hist. Med., 1999, 12: 19-43; idem, 'Practice versus theory: tenthcentury case histories from the Islamic Middle East', Soc. Hist. Med., 2000, 13: 293-306.

${ }^{8}$ The obvious example is Dioscorides' Materia medica. For an Arabic edition see, C E Dubler and E Terés (eds), La "materia médica" de Dioscorides: transmisión medieval y renacentista, 6 vols,

Barcelona, Emporium, 1953-1959; the classic edition
}

is Robert T Gunther (ed.), The Greek herbal of Dioscorides, Oxford University Press, 1934; for a more recent edition, see $\mathrm{T}$ A Osbaldeston and R P A Wood, Dioscorides: De materia medica, Johannesburg, IBIDIS, 2000.

${ }^{9}$ Zohar Amar, The history of medicine in Jerusalem, BAR International Series 1032, Oxford, Archaeopress, 2002, p. 76.

${ }^{10}$ Moshe Ben Maimon (Maimonides), Poisons and their antidotes, ed. Süssmann Muntner, Jerusalem, Mosad Harav Kook, 1942 (in Hebrew), p. 93; Ben Maimon, op. cit., note 1 above, p. 59.

${ }^{11}$ On substitute materials, see Said and Elahie (eds), op. cit., note 4 above, vol. 2, 


\section{Medieval Materia Medica according to the Cairo Genizah}

opportunity to assess the quantities of both the practical and theoretical inventories of the Genizah people, and to display the gap between the two. Moreover, we would like to probe the commercial cycle of physicians, patients, herbalists, pharmacists, merchants, local markets, and international trade in the areas under Islamic rule and cultural/scientific influence.

This being our objective, what can we learn about the practical uses of materia medica? How can we discover the main diseases that afflicted people in the communities under study? And finally, what were the most frequently prescribed medicines and medicinal substances in eastern medieval society?

\section{The Genizah and Research on Medical Issues}

The Genizah's many manuscripts have been studied ever since they were discovered in the late nineteenth century. ${ }^{12}$ Individual fragments have been published, catalogues written, ${ }^{13}$ and much research focusing on a wide variety of matters has yielded a wealth of articles and books. Among the main fields of study have been religious and biblical subjects, Jewish law, education, poetry, social life, trade, communal organization, and so on. The importance of the Genizah for research on medieval Mediterranean communities, supplying as it does information on almost every aspect of life, has been demonstrated by Shlomo Goitein, Moshe Gil, Menahem Ben-Sasson and others. ${ }^{14}$ Medical issues in the Genizah have, however, tended to be researched only as part of other subjects-such as the different professional classes of the Jewish community in Old Cairo. Nevertheless, a number of scholars have dealt with medical matters, including Goitein, Colin Baker, Paul Fenton, Albert Dietrich, Mark Cohen, Esti Dvorjetski, and, especially, Haskell Isaacs. ${ }^{15}$

pp. 42-4; Martin Levey, Substitute drugs in early Arabic medicine, Stuttgart, Wissenschaftliche Verlagsgesellschaft, 1971.

${ }^{12}$ Stefan C Reif, A Jewish archive from Old Cairo: the history of Cambridge University's Genizah collection, Richmond, Surrey, Curzon, 2000, pp.1-22.

${ }^{13}$ For example, Stefan C Reif (ed.), Published material from the Cambridge Genizah Collections: a bibliography 1896-1980, Cambridge University Library Genizah Series 6, Cambridge University Press, 1988; Richard Gottheil and William H Worrell, Fragments from the Cairo Genizah in the Freer Collection, London, Macmillan, 1927; Geoffrey A Khan, Arabic legal and administrative documents in Cambridge Genizah collections, Cambridge University Library Genizah Series 10, Cambridge University Press, 1993; B Helper, Descriptive catalogue of Genizah fragments in Philadelphia, Philadelphia, Dropsie College for Hebrew and Cognate Learning, 1924; Rebecca J W Jefferson and Erica C D Hunter, Published material from the Cambridge Genizah collections: a bibliography 1980-1997, Cambridge University Library Genizah Series 13, Cambridge University Press, 2004.

\footnotetext{
${ }^{14}$ Shlomo D Goitein, A Mediterranean society: the Jewish communities of the Arab world as portrayed in the documents of the Cairo Genizah, 4 vols, Berkeley and London, University of California Press, 1967, vol. 1, p. 210; 1971, vol. 2, p. 253; idem, Palestinian Jewry in early Islamic and Crusader times, Jerusalem, Yad Yitshak Ben Zvi, 1980 (in Hebrew); Moshe Gil, Palestine during the first Muslim period (634-1099), Tel Aviv University and the Ministry of Defense, 1983, vol. 2, pp. 195-6, 200-1 (in Hebrew); idem, In the kingdom of Ishmael, Jerusalem, Tel Aviv University, The Bialik Institute, Jerusalem, and the Ministry of Defense, 1997, vol. 1, pp. 560-6 (in Hebrew); Menahem Ben-Sasson, The Jews of Sicily 825-1068, Jerusalem, Makhon Ben-Tsevi, 1991 (in Hebrew).

${ }^{15}$ Shlomo D Goitein, 'The medical profession in the light of the Cairo Genizah documents', Hebrew Union College Annual, 1963, 34: 177-94; Goitein, A Mediterranean society, op. cit., note 14 above, vol. 2, pp. 266-7, discusses some prescriptions; Colin F Baker, 'Islamic and Jewish medicine in the medieval Mediterranean world: the Genizah evidence', J. R. Soc. Med., 1996, 89: 577-80; P Fenton, 'The importance of the Cairo
} 


\section{Efraim Lev and Zohar Amar}

The current study focuses on the works of Isaacs, Goitein, and others on medicine in the Genizah through a re-examination of the fragments they mention, and many dozens of new fragments identified as medical since Isaacs and Baker's catalogue was published. ${ }^{16}$ Obviously, poring over the fragments for new interdisciplinary research will result in different outcomes from the cataloguing process conducted by Isaacs and Baker. ${ }^{17}$ Our findings reveal that not all medical fragments can be treated as a single group; they fall into different categories according to their literary style and especially their uses. Isaacs and Baker do differentiate between various kinds of fragments-letters, lists and prescriptions ${ }^{18}$-although they frequently do not classify the manuscripts correctly, for example, they describe a medical formula found in part of a book as a prescription. ${ }^{19}$ Most of the data published in their catalogue proves to be based in the theoretical medical literature, that is, medical writings copied from the well-known books of earlier medical authorities, classical (for example, Hippocrates, Galen) as well as Arab (for example, Ibn Sīnā, Ibn al-Bayțār), which were copied in many different versions.

The process of study and analysis of the medical fragments of the Cairo Genizah led us to devise a method of differentiating the types of information found in them. ${ }^{20}$ For example, we can now distinguish theoretical professional medical writings, written in a standard, firm and clear hand (on sheets of the same size and quality, the same number of lines per page, and margins of fixed size) from practical prescriptions, usually scrawled in a vulgar style, no longer than one or two pages, a varying number of lines, margins of various sizes, one side blank, verso inverted in relation to recto or written between the lines or in the margins of books, Bibles, on official documents, on private letters, and even on receipts. ${ }^{21}$

\section{Findings}

We discerned five main groups of medical fragments. Firstly, medical books were copied by professional copyists from works written by physicians and pharmacists. These were classics, of Christian, Muslim, as well as Jewish origin. So far 1360 fragments

Genizah for the history of medicine', Med. Hist., 1980, 24: 347-8; Albert Dietrich, Zum Drogenhandel im islamischen Ägypten, Heidelberg, Carl Winter, 1954; Mark R Cohen, 'The burdensome life of a Jewish physician and communal leader: a Geniza fragment from the Alliance Israelite Universelle Collection', Jerusalem Studies in Arabic and Islam, 1993, 16: 125-36; Esti Dvorjetski, 'The contribution of the Geniza to the study of the medicinal hot springs in Eretz-Israel', in Proceedings of the Twelfth World Congress of Jewish Studies, Jerusalem, 1990, vol. 2, 85-93; Haskell D Isaacs, 'The impact of western medicine on Muslim physicians and their writing in the 17th century', Bull. Br. Ass. Orientalists, 1979-1980, 11: 52-57; idem, 'A medieval Arab medical certificate', Med. Hist., 1991, 35: 250-7; Haskell D Isaacs, with the assistance of Colin F Baker, Medical and para-medical manuscripts in the Cambridge Genizah collections, Cambridge University Press, 1994.

\footnotetext{
${ }^{16}$ Friedrich Niessen and Efraim Lev, 'Addenda to Isaacs' catalogue "Medical and para-medical manuscripts in the Cambridge Genizah collection", Hebrew Union College Annual (forthcoming).

${ }^{17}$ Isaacs and Baker, op. cit., note 15 above.

${ }^{18}$ Ibid., pp. viii-ix.

${ }^{19}$ For an example of a medical formula described by Isaacs and Baker as a prescription, see ibid., pp. 86-7, T-S AS 167.36.

${ }^{20}$ This method is explained in detail in Efraim Lev and Zohar Amar, Practical materia medica of the medieval eastern Mediterranean according to the Cairo Genizah, Leiden, Brill, 2007.

${ }^{21}$ Taylor-Schechter Cairo Genizah Collection at Cambridge University Library: for practical prescriptions, see T-S NS 194.70; for margins of Bibles, see T-S NS 66.46 and T-S NS 279.57; for official documents, see T-S K25.212; for private letters and receipts, see T-S Ar.34.150 and T-S Ar.43.54.
} 


\section{Medieval Materia Medica according to the Cairo Genizah}

of medical books have been identified in the Taylor-Schechter Collection. The books are in Arabic (740), Judaeo-Arabic (470), and Hebrew (150). Isaacs and Baker identified 35 titles. Since then about 15 more titles have been identified by Efraim Lev and Leigh Chipman, and the work is still in progress. ${ }^{22}$ Of the books already identified, roughly onethird were written by pagan classical authorities, including Galen and Hippocrates. Another third were written by Muslim writers, including Sābūr Ibn Sahl, ${ }^{23}$ Ibn Sinā, al-Rāzī, Ibn al-Baytạ̄r, and 'Al̄̄ Ibn 'Īsā. ${ }^{24}$ The remainder are by Jewish physicians, members of the Cairo Jewish community, such as al-Kūhīn al- 'Atțar, Daud Ibn Abī alBayān, ${ }^{25}$ and Maimonides. Maimonides wrote abridged versions of Galen's works De temperamentis and De alimentorum facultatibus. ${ }^{26}$ These texts are preserved only thanks to the Genizah. ${ }^{27}$ Other sources for the reconstruction of the "Genizah medical library" are lists of books owned by private individuals and sold after their deaths. ${ }^{28}$

Al-Kūhīn al-'Atțar's Minhāj al-dukkān was considered in the past-and by scholars today - to be one of the most popular and useful pharmacopoeias of medieval medicine. ${ }^{29}$ Despite its practical character, the book contains much theoretical material (see Figure 1).

Secondly, come the personal notebooks of medical practitioners. Fifty such notebooks have been identified. They contain medical theories, descriptions of methods of healing, and selected prescriptions which were chosen and then copied for their own use by medical students or practitioners from books and famous physicians whom they worked with or under. ${ }^{30}$ From our research into these notebooks, we concluded that most concentrate on one area of medicine, such as ophthalmology, gynaecology, or dentistry (see Figure 2), and only a minority contain recipes for treatment of a variety of complaints. ${ }^{31}$ These notebooks

\footnotetext{
${ }^{22}$ See preliminary report in Efraim Lev, 'Work in progress: the research of medical knowledge in the Cairo Genizah-past, present and future', in Shulie Reif (ed.), The written word remains: the archive and the achievement, Cambridge,

Taylor-Schechter Genizah Research Unit at Cambridge University Library, 2004, pp. 37-51.

${ }^{23}$ Efraim Lev and Leigh Chipman, "A fragment of a Judeo-Arabic manuscript of Sābūr Ibn Sahl al-Aqrābādhīn al-şaghīr found in the Taylor-Schechter Cairo Genizah Collection', Medieval Encounters (forthcoming).

24 'Al̄̄ Ibn 'Īsā, Tadhkirat al-kahhạ̄īnn, Hyderabad, Da'iratu'l-Ma'arif'il-Osmania, 1964.

${ }^{25}$ Leigh Chipman and Efraim Lev, 'Syrup from the apothecary's shop: a Genizah fragment containing one of the earliest manuscripts of Minhāj al-dukkān', Journal of Semitic Studies, 2006, 51: 137-68; Daud Ibn Ab̄̄ al-Bayān, al-Dustūr al-B̄̄māristān̄̄ (in Arabic), in Paul Sbath, 'Le Formulaire des hôpitaux d'Ibn Abil Bayan, médecin du bimaristan Annacery au Caire au XIIIe siècle', Bulletin de l'Institut d'Egypte, 1932-1933, 15: 9-78. See also Efraim Lev, Leigh Chipman, and Friedrich Niessen, 'A hospital handbook for the community: evidence for the extensive use of Ibn Ab̄̄ '1-Bayān's al-Dustūr albìmāristān̄ by the Jewish practitioners of medieval Cairo', Journal of Semitic Studies (forthcoming).
}

\author{
${ }^{26}$ T-S Ar.21.112; T-S Ar.44.51. \\ ${ }^{27}$ Corpus codicum hebraicorum medii aevi, part 1 : \\ Maimonidis commentarius in Mischnam, ed. Solomon \\ D Sassoon, Copenhagen, Munksgaard, 1956, \\ vol. 3, pp. 12-17. \\ ${ }^{28}$ David H Baneth, 'A doctor's library in Egypt \\ at the time of Maimonides', Tarbiz, 1961, 30: 171-85; \\ Miriam Frenkel, 'Book lists from the Genizah \\ as a source for the culture and social history of \\ the Jews in Mediterranean society', in Mordechai \\ Friedman (ed.), A century of Genizah research, \\ Te'uda XV, Tel Aviv University, 1999 (in Hebrew); \\ Shlomo D Goitein, 'Maimonides' life in the light \\ of the Geniza documents', Peraqim, 1966, 4: \\ 29-42. \\ ${ }^{29}$ Leigh Chipman, 'Minhāj al-dukkān by Abū \\ al-Mūna al-Kūhīn al-'Atțar: aspects of pharmacy \\ and pharmacists in Mamluk Cairo', unpublished \\ PhD Dissertation, Jerusalem, The Hebrew \\ University, 2005); Max Meyerhoff, 'Arabic medicine \\ among the Jews of Yemen', Edot, 1948, 3: 27-32 \\ (in Hebrew); Chipman and Lev, op. cit., note \\ 25 above. \\ ${ }^{30}$ The full list of fragments will be given in detail \\ in a future publication. \\ ${ }^{31}$ For ophthalmology, see T-S K14.32; for \\ gynaecology, see T-S Ar.45.21; for dentistry, see \\ T-S Or.1080.7.17.
}




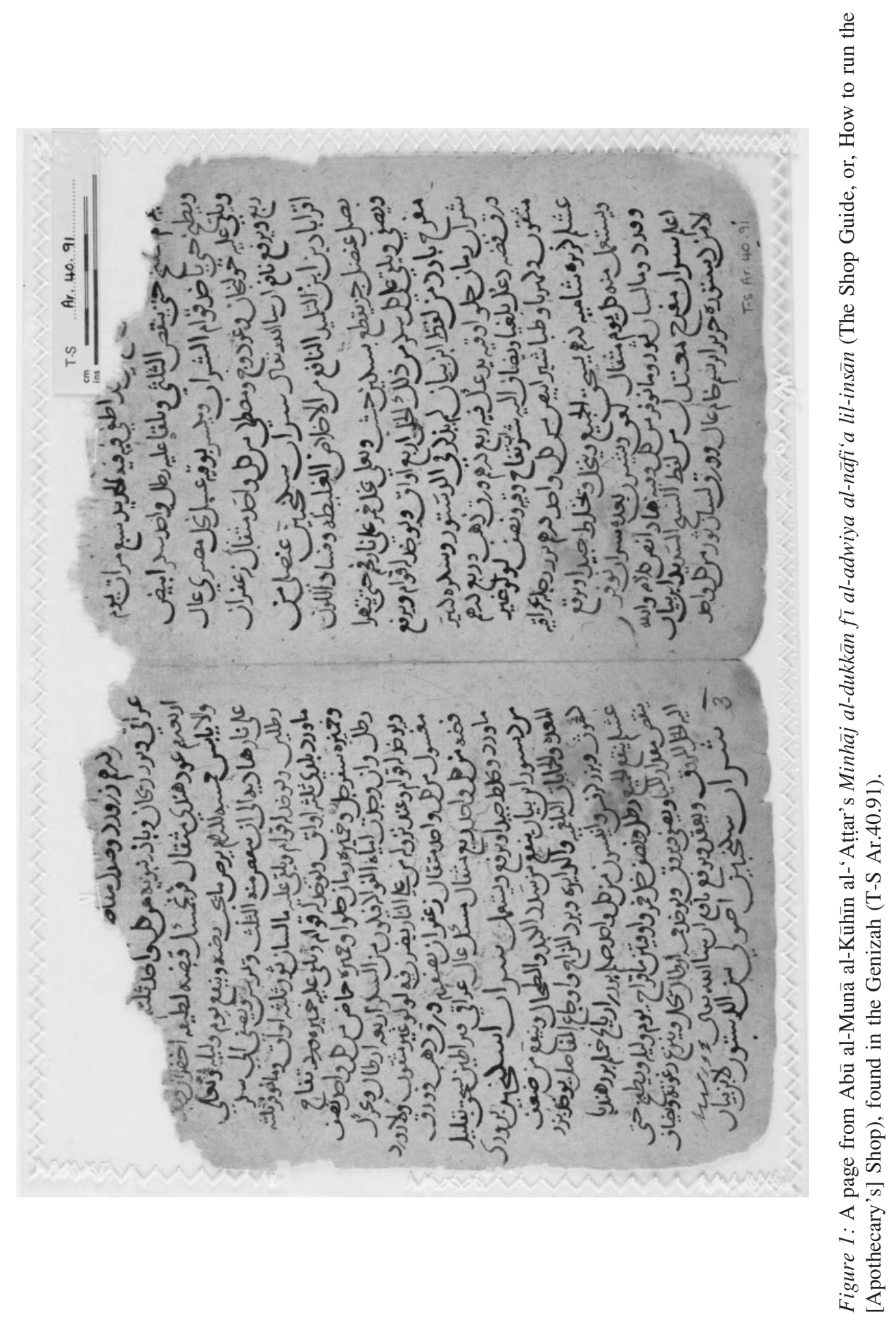




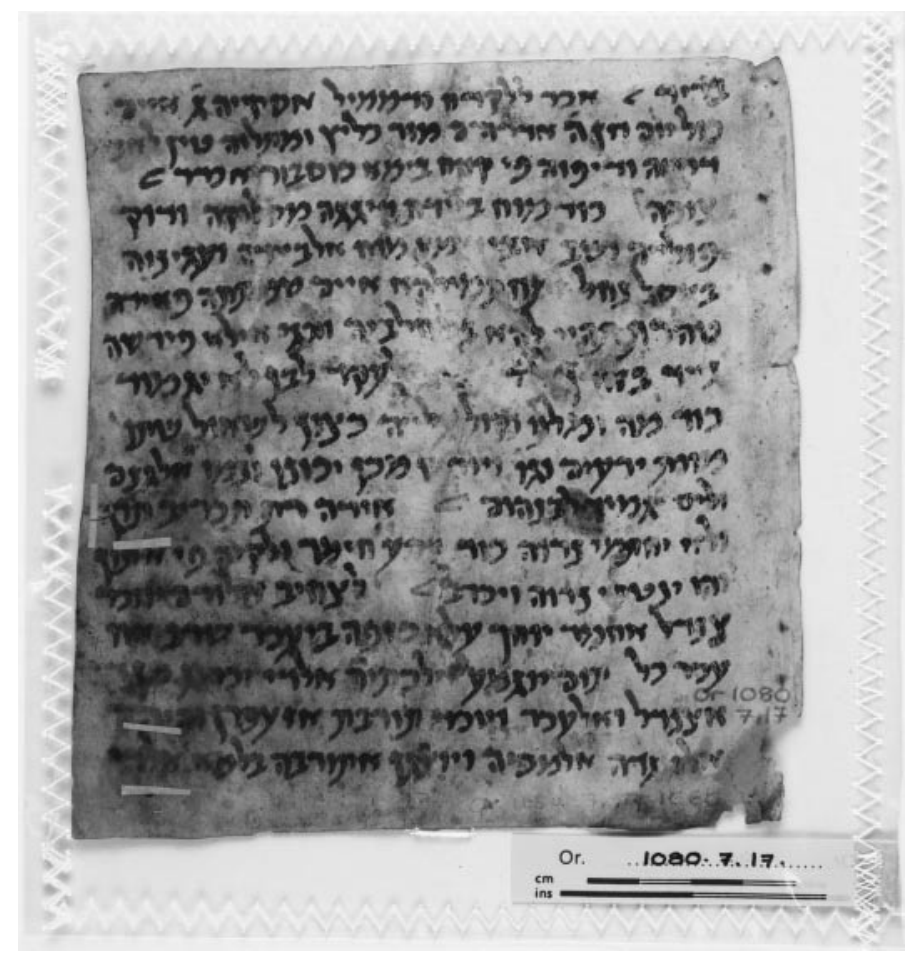

Figure 2: A fragment of a notebook on dentistry (T-S. Or.1080.7.17).

give us a preliminary idea of the most prevalent diseases, and of the medical interests shared by practitioners, patients and other members of the community. It should be mentioned here that diseases are known today as (at least partly) social constructs. Contemporary concerns regarding health and diseases played a role in shaping the medical corpus, including practical prescription.

Thirdly, the letters of medical practitioners and patients, and those sent to medical authorities or institutions provide additional information. Several letters from Maimonides were revealed, in which he gives medical advice and mentions medicinal substances among other issues. ${ }^{32} \mathrm{We}$ consider these particular letters as types of prescription, and so contributory evidence on the practical use of these substances. Another example is a letter from Maimonides in which he recommends drinking two cups of milk a day as a treatment, although, unfortunately, he does not specify the complaint. ${ }^{33}$

Fourthly, there are prescriptions written by physicians after seeing a patient; the recipe (formula) would be made up by a pharmacist. A total of 141 unique original prescriptions

\footnotetext{
${ }^{32}$ T-S Ar.46.97; T-S Ar.30.286.

${ }^{33}$ T-S 10J20.5; Shlomo D Goitein, 'A new autograph by Maimonides and a letter to him
} 


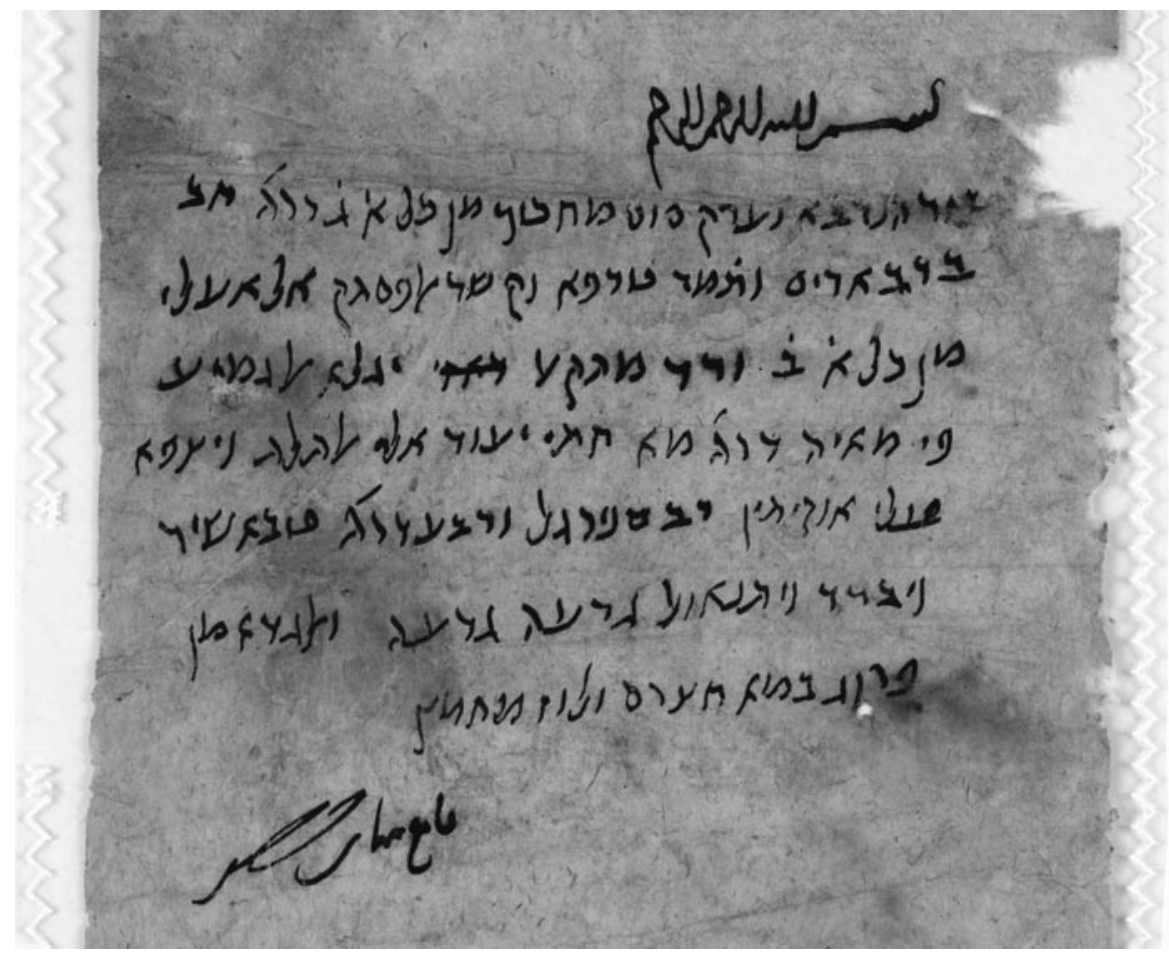

Figure 3: Prescription for a recipe written in Judaeo-Arabic, opening and closing with benedictions in Arabic (T-S Ar.30.305).

were found in the Taylor-Schechter Genizah Collection; of these, 40 were more or less complete. ${ }^{34} \mathrm{~A}$ few more were discovered in other collections. In most cases these are written in Arabic script (92) and Arabic written in Hebrew script (Judaeo-Arabic) (47), the most widely used languages and dialects in the daily life of medieval Cairo. Very rarely Hebrew (1) or Judaeo-Persian (1) is found. In a few cases the prescription is written in Judaeo-Arabic but the benedictions that open and close it are written in Arabic script (see Figure 3). ${ }^{35}$ In one case, the same formula is written in Judaeo-Arabic on one side of the sheet and in Arabic on the other. ${ }^{36}$ In another, two similar versions of the same formula, written in Arabic and headed ma'jün hibat alläh, are found on the same side of a fragment. ${ }^{37}$ The handwriting is usually sloppy and unclear. A few prescriptions were copied identically, others with changes, from famous books such as Minhāj al-dukkān or Dustūr

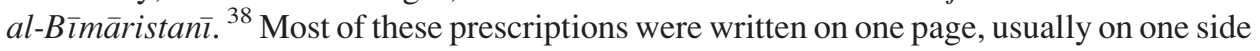

\footnotetext{
${ }^{34}$ This will be discussed in detail in a future publication by Efraim Lev and Leigh Chipman.

${ }^{35}$ For example, T-S Ar.30.305.

${ }^{36} \mathrm{~T}$-S AS 155.365.
}

\footnotetext{
${ }^{37}$ T-S Ar.34.305.

${ }^{38}$ Examples of these are: for identical copies, T-S Ar.42.67 and T-S NS 297.17; prescriptions with changes, T-S Ar.41.81; from famous
} 


\section{Medieval Materia Medica according to the Cairo Genizah}

of a sheet of paper and very rarely on vellum. They were often written on reused paper; at times in the margin or between the lines of other documents or even books. ${ }^{39}$

The most important and interesting information is undoubtedly to be found in the prescriptions. They reflect the medical reality that existed in Cairo, which at times corresponds with that found in books. A unique aspect of the information that emerges from the prescriptions is their originality. Unlike the information derived from books, which are usually copied from classical or contemporary medical sources, the prescriptions are clear-cut primary evidence of the medicinal substances used, and of the medical conditions that afflicted the members of the community, and the ways they were treated.

There are 242 medicinal substances mentioned in the prescriptions, of which 194 are of plant origin (80.1 per cent), 20 are of animal origin (8.3 per cent), and the remaining 28 are inorganic (11.6 per cent). We consider the prescriptions clear-cut evidence of the use of these substances for medicinal purposes and an important element of medical knowledge in its practical form. ${ }^{40}$

Prescriptions can teach us about the prevailing diseases and symptoms that members of the community suffered from, although in most cases neither the symptoms nor the patient's name appear on the prescription. Very few prescriptions have been published so far. Goitein discusses one on how to become stout; and publishes the translation of another; it is not clear for what condition it was prescribed. ${ }^{41}$

Still, analysis of the prescriptions and some of the notebooks with the help of contemporary pharmacopoeias shows eye diseases to have been the most prevalent ailments. Many dozen fragments concerned with ophthalmology deriving from many medical books dealing with eye diseases (especially 'Alī Ibn 'İsā's Tadhkirat al-kaḥhāī̄n) are further evidence of this. ${ }^{42}$ Other ailments include skin diseases, headaches, fevers, internal diseases (liver), intestinal problems, and haemorrhoids, as well as urinary trouble, ulcers, swellings, cough, and gynaecological illnesses. A few of the formulas were copied from theoretical medical literary sources. These are mainly works such as al-Kūhīn al- 'Atțāar's Minhāj al-dukkān or Ibn Ab̄̄ al-Bayān's Dustūr al-bīmāristānn̄̄ ${ }^{43}$

Finally, there are the lists of materia medica. These may be of various origins: inventories of pharmacies compiled for establishing or dissolving partnerships, for commercial orders, or for tax purposes; pharmacists' invoices and order forms for substances, especially those of wholesalers sent to retailers, or of pharmacists sent to wholesalers. These are among the best sources for the study of practical materia medica

books, T-S Ar.30.65, T-S Ar.39.274 and T-S Ar.41.71.

${ }^{39}$ For example, T-S NS 194.70.

${ }^{40}$ For the complete list of the identified prescriptions, including information on each one of them, see Lev and Amar, op. cit., note 20 above, Appendix 5.

${ }^{41}$ For stoutness, see Goitein, A Mediterranean society, op. cit., note 14 above, vol. 2, p. 581 n.3, regarding MS D.W. Amram, f. 2v (held in the library of the University of Pennsylvania, Philadelphia); the other prescription is in T-S Ar.30.65, see Goitein, ibid., p. 267.

${ }^{42}$ Isaacs and Baker, op. cit., note 15 above, see indices.

${ }^{43}$ See T-S Ar.30.65; T-S Ar.39.274; T-S Ar.41.71, for formulas copied from Abū al-Munā al-Kūhīn al-'Ațtar, op. cit., note 3 above; see T-S Ar.42.67; T-S NS 297.17; T-S Ar.41.81; T-S Ar.41.81, for formulas copied from al-Bayān, see Sbath, op. cit., note 25 above. 


\section{Efraim Lev and Zohar Amar}

and the reconstruction of the community's inventory of practical materia medica. Goitein, for example, draws attention to one invoice for two consignments, one of 54 items, another of 34 . The drugs listed are known from other sources, but in this case all were carried at the same time by one retailer; the fragments mention weights and prices as well (see Figure 4). ${ }^{44}$ Invoices to individuals are common, and they teach us about transactions, payments, and medicinal substances used at that time. Some invoices note quantities and prices, others show only the prices. ${ }^{45}$

In general, the 71 original materia medica lists found in the Genizah lack any headings that might explain their uses. However, since they are different from merchants' letters dealing with trade in materia medica and give no instructions for the use or preparation of formulas (as is usually found in prescriptions), they were identified as materia medica lists. Some of these lists are written in Judaeo-Arabic (26), but the vast majority are in Arabic (45), none is in Hebrew. In some cases they appear as rows with written quantities, in others they are written as long columns, sometimes on very narrow and long or large sheets of paper. ${ }^{46}$ Occasionally the quantities are in Arabic words, at other times in Hebrew script, in a few cases in Coptic numerals. ${ }^{47}$ These lists were apparently used by pharmacists for professional and business purposes as inventories of materia medica, records, orders, or even receipts. Orders to the sharāa $\bar{l}$ (sellers of potions) were also found and studied. ${ }^{48}$

The lists point directly to the existing trade in these substances and the place they occupied on the shelves of the pharmacies found in the lanes and alleys of the Jewish quarter of Cairo. However, they vary considerably in size. The average number of substances on the short lists (up to 10 substances) is 6, and on the long ones (more than 10 substances) it is 26 . The longest list contains 63 identified substances. Two hundred and six medicinal substances are mentioned in all the lists, of which 167 (81 per cent) are of plant origin, 16 are of animal origin ( 7.8 per cent), and the remaining 23 are inorganic (11.2 per cent). ${ }^{49}$

In addition to the lists, merchants' letters contain excellent information on other aspects of this trade: they mention drugs' names and their origin, and we can learn about routes and other aspects of the drug trade of that era, for example, between Cairo and Alexandria. ${ }^{50}$ Also, there is information on imports of drugs to port cities, for example to the Rif and Cairo. ${ }^{51}$ One such fragment describing the trade in medicinal substances between India and other countries in the Far East and Egypt is discussed by Dietrich. ${ }^{52}$ A large number of the substances mentioned in merchants' letters were also used by members of this medieval society as foodstuffs, spices, and condiments, and in industries such as tanning, dyeing, etc.

\footnotetext{
${ }^{44} \mathrm{~T}$-S Ar.30.274, discussed in Goitein, $A$ Mediterranean society, op. cit., note 14 above, vol. 2 , p. 268.

${ }^{45}$ T-S Ar.30.165.

${ }^{46}$ For rows with written quantities, see T-S Ar.35.229 and T-S Ar.43.315; for columns, see T-S Ar.30.274 and T-S Ar.39.450; for varying sized paper, see T-S Ar.39.487.

${ }^{47}$ For quantities in Arabic words, see T-S AS 179.56; for quantities in Hebrew script,
}

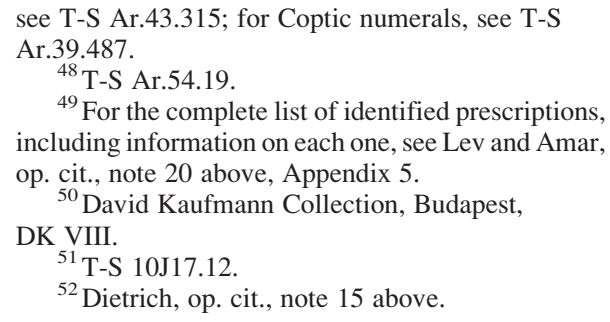

${ }^{49}$ For the complete list of identified prescriptions, including information on each one, see Lev and Amar, op. cit., note 20 above, Appendix 5.

${ }^{50}$ David Kaufmann Collection, Budapest, DK VIII. 


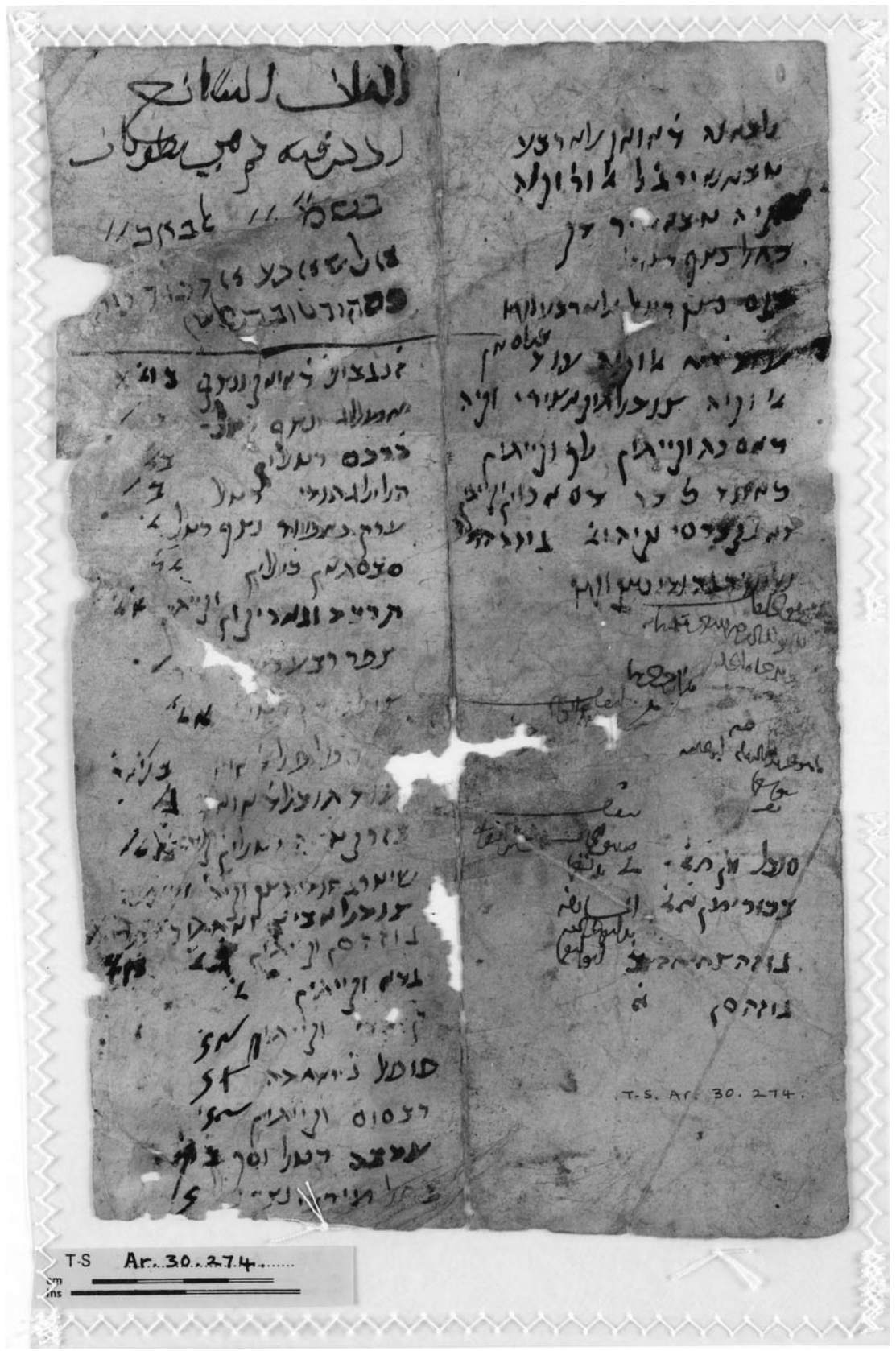

Figure 4: List of simples and their quantities, written in Judaeo-Arabic, including weights or prices in Coptic numerals (T-S Ar.30.274). 


\section{Efraim Lev and Zohar Amar}

However, these documents were not used as main sources for our research since they do not have a direct relevance for medicinal uses.

\section{Discussion}

This section of the paper has assessed the information contained in the Genizah collections in relation to the medicine practised in the Mediterranean Arab world in the medieval period, and the contribution of the Arabs to medicine and pharmacy, mainly as regards medicinal substances. ${ }^{53}$ We also consider the theoretical inventory of materia medica, which is based on medieval medical books found in the Genizah. The presentation, analysis, and comparison of these two types of knowledge are the core of this article, although other related subjects are addressed too.

As we have seen, the advantages of the prescriptions and personal letters lie in bringing together authentic information which reflects the reality of practice; in particular the names of common diseases and drugs in the medieval period. On the other hand, it is possible and even necessary to confront and verify our conclusions with the theoretical medical literature written in the same period regarding specific diseases.

We can presume that most of these theoretical books were written to address contemporary Egyptian health needs. The books cover medical issues such as eye diseases, haemorrhoids, sexual diseases, asthma, etc. In this sense, Maimonides's texts reflect a representative model; according to his testimony, he wrote these books for the Ayyubid rulers (1187-1250), sometimes for the needs of the public, as in the case of his book on poisons, ${ }^{54}$ or for the personal requirements of the ruler. In both cases, these books reflect medical issues among the influential upper socio-economic strata. In the case of the prescriptions, we can presume that they partly reflect the experiences of the lower strata as well. These texts, therefore, open a new window for modern scholars, through which they can widen their knowledge regarding the diseases from which the Egyptian medieval population suffered and the drugs they used to heal themselves.

\section{Inventory of Theoretical Materia Medica of the Medieval Genizah People}

In addition to the four types of practical text discussed above, the Cairo Genizah collections contain extensive theoretical medical writings. The nature of these writings clearly distinguishes them from the practice-based texts. Thus the sampled inventory of

\footnotetext{
${ }^{53}$ For more information on these areas, see Lawrence I Conrad, 'The Arab-Islamic medical tradition', in Lawrence I Conrad, Michael Neve, Vivian Nutton, Roy Porter and Andrew Wear, The western medical tradition 800 BC to AD 1800, Cambridge University Press, 1995, pp. 93-138; Peter E Pormann and Emilie Savage-Smith, Medieval Islamic medicine, Edinburgh University Press, 2007; Emilie Savage-Smith, 'Medicine', in Roshdi Rashed (ed.), Encyclopedia of the history of Arabic science, 3 vols, London Routledge, 1996,
}

vol. 3, pp. 903-62; Mohammad Ali and J S Qadry, 'Contribution of Arabs to pharmacy', Stud. Hist. Med., 1982, 6: 43-53; Sami Hamarneh, 'Development of pharmacy, ancient times to Middle Ages', Stud. Hist. Med., 1982, 6: 37-42; idem, 'The rise of professional pharmacy in Islam', Med. Hist., 1962, 6: 59-63; idem, 'The climax of medieval Arabic professional pharmacy', Bull. Hist. Med., 1968, 42: 450-61.

${ }^{54}$ See Ben Maimon, op. cit., note 10 above. 


\section{Medieval Materia Medica according to the Cairo Genizah}

Table 1

Division by substance origin of historical theoretical medicinal inventories

\begin{tabular}{lrrrrrrrrrrrr}
\hline Origin & \multicolumn{1}{c}{ TG } & $\%$ & \multicolumn{1}{c}{ ML } & \multicolumn{1}{c}{$\%$} & \multicolumn{1}{c}{ MG } & $\%$ & AK & $\%$ & DI & $\%$ & HP & $\%$ \\
\hline Plant & 310 & 74.8 & 234 & 81.8 & 385 & 83.9 & 250 & 83.6 & 600 & 69.4 & 230 & 91.6 \\
Inorganic & 69 & 16.7 & 15 & 5.2 & 42 & 9.1 & 27 & 9 & 96 & 11.2 & 15 & 6 \\
Animal & 35 & 8.5 & 27 & 9.5 & 28 & 6.1 & 22 & 7.4 & 168 & 19.4 & 6 & 2.4 \\
Other & - & - & 10 & 3.5 & 4 & 0.9 & - & - & - & - & - & - \\
\hline Total & 414 & 100 & 286 & 100 & 459 & 100 & 299 & 100 & 864 & 100 & 251 & 100 \\
\hline
\end{tabular}

Sources:

$\mathrm{TG}=$ Theoretical Genizah; ML = medieval Levant medical literature and commercial sources; $\mathrm{MG}=$ Maimonides; $\mathrm{AK}=$ al-Kindī; $\mathrm{DI}=$ Dioscorides; $\mathrm{HP}=$ Hippocrates.

theoretical materia medica mentioned in fragments of medical books found in the Cairo Genizah consists of 414 substances. ${ }^{55}$ Of these, 310 are of plant origin (74.8 per cent), 35 are of animal origin (8.5 per cent), and 69 are of inorganic origin (16.7 per cent). The number of substances of animal origin is proportionately much the same as in the prescriptions, but some are exotic and would be very hard to obtain, for example, elephant bile, wolf gall, hyena bile, crow's gall, bear bile, lion bile, medical skink, and rhinoceros fat.

For the sake of comparison and context, several other theoretical inventories of materia medica have been reconstructed, studied, and analysed on the basis of books written by classical as well as medieval medical authorities. The sources for these are: TGTheoretical Genizah (based on medical literature found in Cairo Genizah); ${ }^{56}$ ML-medieval Levant (based on both medieval medical literature and commercial sources); ${ }^{57} \mathrm{MG}$-Maimonides (thirteenth century AD; based on his translated book); ${ }^{58}$ $\mathrm{AK}$ - al-Kindī (tenth century AD; based on his translated book); ${ }^{59} \mathrm{DI}$-Dioscorides (first century AD; based on his translated book); ${ }^{60}$ and $\mathrm{HP}$ - Hippocrates (fourth century $\mathrm{BC}$; based on Riddle's analysis). ${ }^{61}$

It is clear from these sources (see Table 1) that theoretical inventories consisted of a fairly large number of substances, between 250 and 864 . The theoretical inventory of the Genizah people, consisting of 414 substances, lies more or less in the middle.

\footnotetext{
${ }^{55}$ Although we transcribed many fragments of medical books, and so did Isaacs, not all the books used by members of the community have survived, nor were all the revealed fragments transcribed. The numerical information given here is thus not final or definitive.

${ }^{56}$ Lev and Amar, op. cit., note 20 above, ch. 5 and Appendices 1 and 2.

${ }^{57}$ Efraim Lev, Medicinal substances of the medieval Levant, Tel-Aviv, Eretz, 2002 (in Hebrew); Efraim Lev, 'Reconstructed materia medica of the
}

medieval and Ottoman al-Sham', J. Ethnopharmacol., 2002, 80: 167-79.

${ }^{58}$ Moshe Ben Maimon (Maimonides), Un glossaire de matière médicale composé par Maimonide, ed. and trans. Max Meyerhof, Mémoires de l'Institut d'Égypte, vol. 41,

Cairo, Institut française d'archéologie orientale, 1940.

${ }^{59}$ Levey, op. cit., note 3 above.

${ }^{60}$ Gunther (ed.), op. cit., note 8 above.

${ }^{61}$ John M Riddle, 'Folk tradition and folk medicine: recognition of drugs in Classical Antiquity', 


\section{Inventory of Practical Materia Medica of the Medieval Genizah People}

As noted, the reconstructed inventory of practical materia medica is based on medicinal substances that feature in prescriptions and letters written by medical practitioners of the Jewish community of Cairo, and recorded in materia medica lists compiled by pharmacists, drug sellers, and drug traders. These medicinal substances were identified, studied, arranged in a database and analysed. The inventory comprises 278 substances, of which 223 (80.2 per cent), the great majority, are of plant origin; 31 substances (11.2 per cent) are of inorganic origin, and 24 (8.6 per cent) are of animal origin.

A further concern was to evaluate and analyse the data and subdivisions of the reconstructed inventory of the Genizah people by comparison with present-day traditional practical inventories of various ethnic groups, as well as traditional societies with a similar social background and of the same geographical area, namely the Middle East and North Africa. These data (see Table 2) were taken from surveys of markets in Egypt, Israel, Jordan and Syria, and from inventories resulting from studies of medicinal substances used by Jewish and Muslim ethnic groups: ${ }^{62}$ inventory of practical medieval usage as evidenced by the Genizah (PG); ${ }^{63}$ Cairo markets, nineteenth to twentieth century (EG); ${ }^{64}$ survey of markets in Israel (MIS); ${ }^{65}$ survey of markets in Syria $(\mathrm{SY}) ;{ }^{66}$ survey of markets in Jordan (JO); ${ }^{67}$ survey of markets in Morocco (MO); ${ }^{68}$ Yemeni Jews in Israel (YJ); ${ }^{69}$ Iraqi Jews in Israel (IJ); ${ }^{70}$ and Bedouins in southern Israel (Negev) (NB). ${ }^{71}$ Table 2 clearly shows that the size of the Genizah's practical materia medica inventory (278 substances) is close to the average size (285) of the other

in John Scarborough (ed.), Folklore and folk medicine, Madison, WI, American Institute for History of Pharmacy, 1987, pp. 33-61.

${ }^{62}$ Information on the uses of materia medica among ethnic groups such as Yemeni or Iraqi Jews in Israel reflects minority groups dwelling far from their places of origin, therefore, the data may be incomplete by comparison with those in the country of origin.

${ }^{63}$ Lev and Amar, op. cit., note 20 above.

${ }^{64}$ Max Meyerhof, 'Der Bazar der Drogen und Wohlgerüche in Kairo', Archiv fur Wirtschaftsforschung im Orient (Weimar), 1918, pp. 1-40, 185-218; A H Ducros, 'Essai sur le droguier populaire arabe de l'inspectorat des pharmacies du Caire', Mém. de l'Inst. Egypte, 1930, 15: 1-162; J Worth Estes and Laverne Kuhnke, 'French observations of disease and drug use in late eighteenth-century Cairo', J. Hist. Med. Allied Sci., 1984, 39: 121-52.

${ }^{65}$ Efraim Lev and Zohar Amar,

'Ethnopharmacological survey of traditional drugs sold in Israel at the end of the 20th century', J. Ethnopharmacol., 2000, 72: 191-205; Efraim Lev and Zohar Amar, Ethnic medicinal substances of the land of Israel, Jerusalem and Tel Aviv, Yerid Hasfarim-Eretz, 2002 (in Hebrew).

\footnotetext{
${ }^{66}$ Gisho Honda, Wataru Miki and Mitsuko Saito, Herb drugs and herbalists in Syria and North Yemen, Tokyo, Institute for the Study of Languages and Cultures of Asia and Africa, 1990; Floreal Sanagustin, 'Contribution à l'étude de la matière médicale traditionnelle chez les herboristes d'Alep', Bulletin d'Etudes Orientales, 1983, 31: 65-112.

${ }^{67}$ Efraim Lev and Zohar Amar, 'Ethnopharmacological survey of traditional drugs sold in the kingdom of Jordan', J. Ethnopharmacol., 2002, 82: 131-45.

${ }^{68}$ M Salah Ahmed, Gisho Honda and Wataru Miki, Herb Drugs and Herbalists in the Middle East, Tokyo, Institute for the Study of Languages and Cultures of Asia and Africa, 1979.

${ }^{69}$ Yocheved Ria'ani, 'Medicinal drugs of the Yemenite Jews', MSc Thesis, School of Pharmacy, the Hebrew University in Jerusalem, 1963 (in Hebrew).

${ }^{70}$ Abraham Ben-Ya'akov, The traditional medicine of the Babylonian Jews, Jerusalem, Yerid Hasefarim, 1992 (in Hebrew).

${ }^{71}$ Aref Abu-Rabia, Traditional Bedouin medicine, Tel Aviv, Ministry of Defense, 1999 (in Hebrew).
} 


\section{Medieval Materia Medica according to the Cairo Genizah}

Table 2

Division by origin of traditional medicinal substance inventories of some countries and Jewish and Muslim ethnic groups

\begin{tabular}{lrrrrrrrrrrrrrrrrrr}
\hline Origin & PG & $\%$ & EG & $\%$ & MIS & SY & S & JO & $\%$ & MO & $\%$ & YJ & $\%$ & IJ & $\%$ & NB & $\%$ \\
\hline Plant & 223 & 80.2 & 417 & 82.7 & 264 & 85.1 & 189 & 77.5 & 236 & 77.6 & 273 & 88 & 151 & 83 & 150 & 82.9 & 193 & 77.2 \\
Inorganic & 31 & 11.2 & 46 & 9.1 & 19 & 6.1 & 31 & 12.7 & 30 & 9.8 & 25 & 8.1 & 10 & 5.5 & 15 & 8.3 & 15 & 6 \\
Animal & 24 & 8.6 & 41 & 8.2 & 20 & 6.5 & 11 & 4.5 & 29 & 9.6 & 12 & 3.9 & 21 & 11.5 & 16 & 8.8 & 42 & 16.8 \\
Other & - & - & - & - & 7 & 2.3 & 13 & 5.3 & 9 & 3 & - & - & - & - & - & - & - & - \\
\hline Total & 278 & 10 & 504 & 100 & 310 & 100 & 24 & 100 & 304 & 100 & 310 & 100 & 182 & 100 & 181 & 100 & 250 & 100
\end{tabular}

Sources:

$\mathrm{PG}=$ inventory of practical medieval usage as found in the Genizah.

$\mathrm{EG}=$ Cairo markets, nineteenth to twentieth century.

MIS $=$ survey of markets in Israel.

$\mathrm{SY}=$ survey of markets in Syria.

$\mathrm{JO}=$ survey of markets in Jordan.

$\mathrm{MO}=$ survey of markets in Morocco.

$\mathrm{YJ}=$ inventory of medicinal substances used by Yemeni Jews in Israel.

$\mathrm{IJ}=$ inventory of medicinal substances used by Iraqi Jews in Israel.

$\mathrm{NB}=$ inventory of medicinal substances used by Negev Bedouins.

inventories that appear in the table. The division of the contents of traditional inventories of present-day Middle Eastern societies and ethnic groups by substance origin is also similar, in absolute figures and percentages.

\section{Conclusions}

Three main conclusions emerge from our findings and analysis, and we present them here separately according to their logical sequence. Diagram A attempts graphically to present the complex medieval web of medicinal substances. It displays various factors, their relationships, and their effect on the theoretical and practical inventory of materia medica in the Jewish community of Cairo as an example of medieval society. The continuous lines represent the transfer of materia medica or knowledge from one factor to the other. The broken lines represent the control of the hisba (market inspection). Actual demand is depicted in the centre and was generated by the market, firstly through the customers (for example, patients) and affected mainly the practical inventory of materia medica. On the other hand, at the top of the diagram, the theoretical inventory lies within the category of textual medical and pharmacological knowledge.

\section{The Gap between the Theoretical and Practical Materia Medica Inventories of the Medieval Genizah People}

In the introduction we presented several questions and hypotheses that were before us while we conducted our research. The first research question was, is there a gap between theoretical and practical medicinal substances, and the second was, what is the ratio of the 
Efraim Lev and Zohar Amar

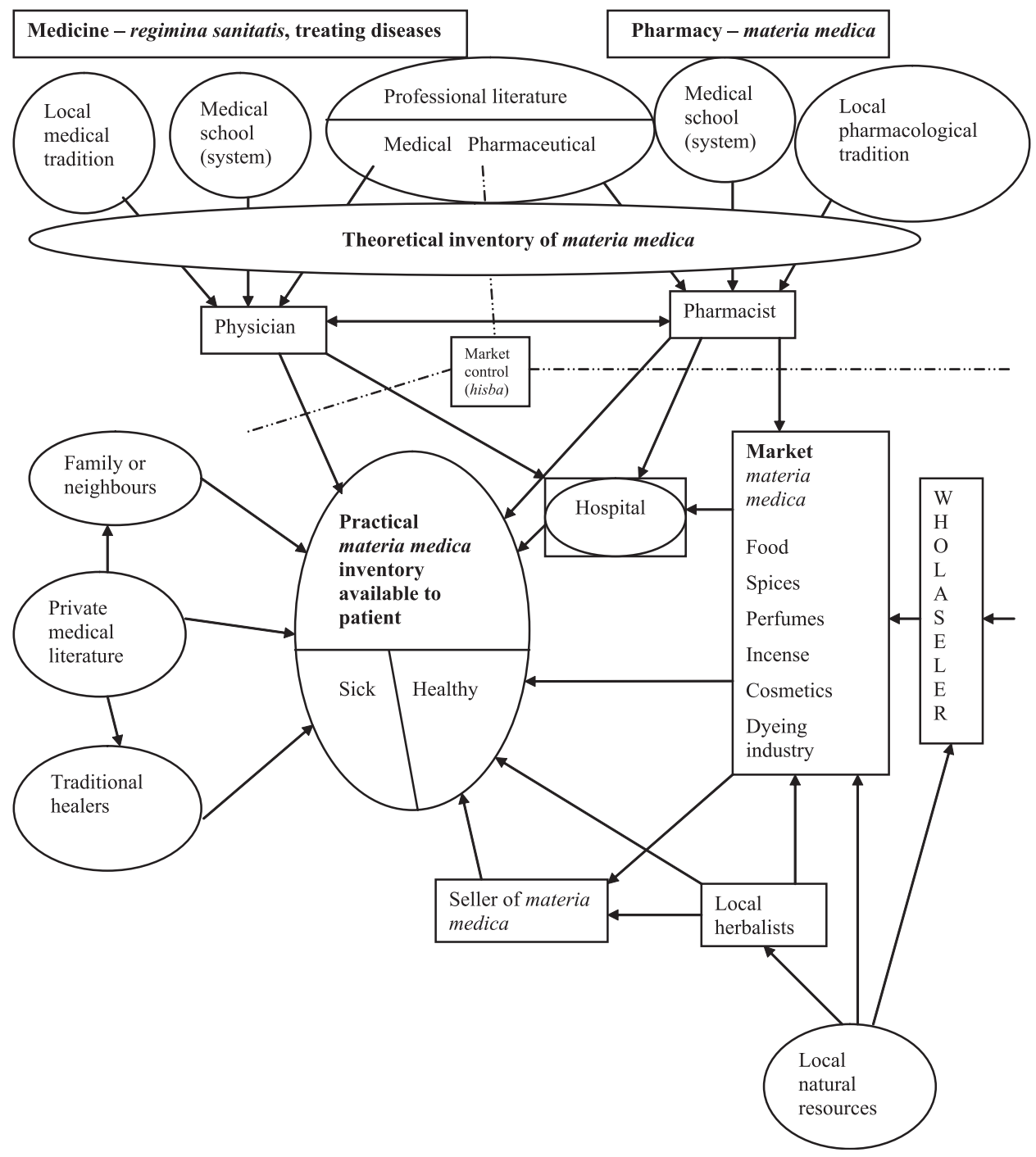

Diagram A: Influential factors on the inventory of the practical medieval materia medica of Mediterranean society.

two groups, and what is the size of the gap? The hypothesis was that the Cairo Genizah documents would help us detect such a gap and even measure it.

It appears very clear that the theoretical inventory of the Genizah people was much larger than the practical one. Therefore, regarding the first question we can definitely answer that a gap of 136 substances exists, of which 87 are of plant origin (64 per cent), 38 of animal origin (27.9 per cent) and 11 are of inorganic origin (8.1 per cent). This gap 


\section{Medieval Materia Medica according to the Cairo Genizah}

separates the theoretical list (mentioned in books), consisting of 414 substances, from the practical one (mentioned in prescriptions, letters, and lists of materia medica) consisting of 278 substances. ${ }^{72}$ This gap is especially conspicuous considering that a few of the substances mentioned in the practical literature are mentioned frequently in the medieval theoretical medical literature on the one hand, ${ }^{73}$ and are used intensively in contemporary traditional medicine on the other. These particular substances can be found in Middle Eastern and North African markets to the present day, for example, Jew's stone, nightshade, lupin, and sweet lime. Lupin and sweet lime were grown and used as foods in Egypt itself.

Regarding the second question, the ratio between the two groups is not easily determined. The numerical answer is that the gap consists of more than one-third (33.8 per cent) of the total number of materia medica mentioned in books, prescriptions, and materia medica lists. However, this picture is very complex and contingent on many factors that sustain each other in a delicate and interesting web. The different inducing factors are the patients, their families, local healers, learned physicians, pharmacists, drug sellers, herbalists, market supervisors, traders, wholesalers, and professional medical literature. Remnants of such a web, on a smaller scale, can be found and studied in the traditional medicine system that still exists in some Arab countries. We discovered this phenomenon when we studied the inventory of substances of traditional medicine in Israel. ${ }^{74}$ It became clearer through another ethno-pharmacological survey conducted in the kingdom of Jordan, as a result of which we tried to explain diagramatically the geographical relations of dealers in Jordan, other Arab countries, and Israel. ${ }^{75}$ A written illustration of the power of one of these factors emerges from the citation from Maimonides' book (given in the introduction). He fervently recommends to the Muslim ruler al-Afdal that the court pharmacy be supplied with the best substances possible, thereby enlarging the practical inventory of materia medica of the medieval Egyptian court according to the medical literature (theoretical inventory). ${ }^{76}$ The theoretical medical knowledge derived from the medical books was undoubtedly the firmest textual foundation for the practical treatment applications of contemporary practitioners, but clearly they used only a fraction of it.

The twenty most frequently mentioned, hence used, substances are presented in Table 3 . This list can teach us about market demands, trade, economy, and practical medical trends. All these substances are of plant origin, apart from salt and honey. A few may have been of local provenance, such as gum arabic and sugar, while others were brought from the Levant (almonds, rose, endive). Many others were obviously imported into Egypt from south-east Asia (pepper, myrobalan, camphor, spikenard) and others from the western Mediterranean (saffron, lentisk).

\footnotetext{
${ }^{72}$ For a detailed list of theoretical materia medica, see Lev and Amar, op. cit., note 20 above, ch. 5, Appendices 1 and 2.

${ }^{73}$ For example, Sami Hamarneh, 'Arabic texts available to practitioners of the health professions in Medieval Islam', Bulletin de l'Institute d'Egypt, 1966-1968, 48-49: 63-7.
}

\footnotetext{
${ }^{74}$ See both articles by Lev and Amar, op. cit., note 65 above.

${ }^{75}$ Lev and Amar, op. cit., note 67 above.

${ }^{76}$ Ben Maimon, op. cit., note 10 above, p. 82; Ben Maimon, op. cit., note 1 above, p. 59.
} 


\section{Efraim Lev and Zohar Amar}

Table 3

The twenty medicinal substances most frequently used by members of the Jewish community of old Cairo according to the Genizah fragments

\begin{tabular}{lll}
\hline English name & Scientific name & No. of times mentioned \\
\hline Myrobalan & Terminalia sp & 79 \\
Rose & Rosa sp. & 71 \\
Almond & Amygdalus communis & 41 \\
Pepper & Piper nigrum & 34 \\
Endive (chicory) & Cichorium intybus & 34 \\
Saffron & Crocus sativus & 34 \\
Spikenard (nard) & Nardostachys jatamansi & 32 \\
Liquorice & Glycyrrhiza glabra & 32 \\
Sugar cane & Saccharum officinarum & 31 \\
Lentisk & Pistacia lentiscus & 31 \\
Grape vine & Vitis vinifera & 29 \\
Salt & NaCl & 26 \\
Basil & Ocimum basilicum & 24 \\
Bugloss & Anchusa sp. (italica and officinalis) & 24 \\
Honey & & 23 \\
Gum arabic & Acacia nilotica & 21 \\
Aloe & Aloe sp. & 21 \\
Sesame & Sesamum indicum & 21 \\
Lemon & Citrus limon & 20 \\
Camphor & Cinnamomum camphora & 20
\end{tabular}

The reconstructed inventory of practical materia medica points directly to the existing trade in these substances and the place they occupied on the shelves of the pharmacies located in the Jewish quarter of Cairo. ${ }^{77}$ Egypt was one of the production centres of substances such as alum, cassia, flax, gum arabic, purging cassia, and sugar, but these

\footnotetext{
${ }^{77}$ For works on trade in the medieval Mediterranean of particular relevance to this essay, see Eliyahu Ashtor, 'Il regno dei crociati e il commercio di Levante', in Gabriella Airaldi and Benjamin Z Kedar (eds), I Communi Italiani nel Regno Crociato di Gerusalemme. Atti del Colloquio, University of Genoa, Istituto di Medievistica, 1986, pp. 15-56; Eliyahu Ashtor, 'The crusader kingdom and trade in the Levant', in Benjamin Z Kedar (ed.), The crusaders in their kingdom, Jerusalem, Yad Yitshak Ben Zvi, 1978, pp. 30-54 (in Hebrew); Eliyahu Ashtor, 'Spice prices in the Near East in the 15th century', J.R. Asiatic Soc., 1976, 1: 26-41; Eliyahu Ashtor, 'Levantine sugar industry in the late Middle Ages', in Abraham L Udovitch (ed.), The Islamic Middle East, 700-1900: studies in economic and social history,
}

Princeton, Darwin Press, 1981, pp. 91-132; Eliyahu Ashtor, 'European trade in the late medieval land of Israel', in Benjamin Z Kedar, Trude Dothan, Samuel Safrai (eds), Commerce in Palestine throughout the ages, Jerusalem, Yad Yitshak Ben Zvi, 1990, pp. 280-99 (in Hebrew); Eliyahu Ashtor and Gabriella Cervidalli, ' Levantine alkali ashes and European industries', J. Europ. Econ. Hist., 1983, 12: 493-500; Goitein, Mediterranean society, op. cit., note 14 above, mainly vol. 1, pp. 153-4, 209-22; Gil, Palestine, op. cit., note 14 above; Yaacov Lev (ed.), Towns and material culture in the medieval Middle East, Leiden, Brill, 2002; Ben-Sasson, op. cit., note 14 above; Dietrich, op. cit., note 15 above; Norman A Stillman, 'The eleventh century merchant house of Ibn 'Awkel', J. Econ. Soc. Hist. Orient, 1973, 16: 15-88; David 


\section{Medieval Materia Medica according to the Cairo Genizah}

are a minority in the inventory. Here, however, we have chosen to set out the broad spectrum of medicinal substances traded and used in Egypt. Some were imported from India and south-east Asia, for example, cubeb, cinnamon, clove, galingale, indigo, pepper, myrobalan, camphor, and spikenard. ${ }^{78}$ Others came from Yemen (alum, mineral mummy, screw pine), Arabia (frankincense, balm of Gilead, sweet-flag), North Africa (coral, saffron, olive oil, soap, honey and wax), Sicily (alum, coral, lead, sulphur, silk, cheese), Crete (cheese, dodder of thyme), Europe (cheese, coral, honey, saffron, lentisk, silk, copper, iron, lead, mercury, earth, silver), and the Levant (asphalt, almonds, rose, dried fruits, endive, gull nuts, scammony, olive oil, soap, sumac, wax). Yet other substances were exported from Egypt to south-east Asia (dodder of thyme, saffron), North Africa (flax, different spices), Sicily (flax, indigo, pepper, cinnamon, clove, sal ammoniac), Europe (alum, pepper, cinnamon, clove, sugar), and the Levant (safflower, meadow saffron, henna, purging cassia, mummy, salep, aniseed).

A study of similar issues in the medieval Levant showed that out of the 268 medicinal substances recorded as being used medicinally, 99 were traded. Twenty-two substances, mainly spices from Asia, were transhipped through the Levant (to Europe), 16 others were imported only, and 61 were exported, mainly to Egypt (33) and Europe (25). Among the exports to Egypt were almonds, bean trefoil, berberry, bugloss, common wormwood, dog rose, fig, grape vine, honey, hyssop, Jew's stone, mung bean, oak gall, olive oil, pear, peony, pistachio nuts, pistacio resin, quince, saffron, stone pine, styrax, sumac, tragacanth, wax, and white melilot. ${ }^{79}$

The widespread commerce in medicinal substances among the different trading centres in the medieval period will be discussed in detail elsewhere. ${ }^{80}$ But the first signs of such activities may be seen in a book attributed to al-Jāhiz (tenth century), ${ }^{81}$ and in the story of the Radhanite merchants, who originated in the north-eastern part of Baghdad. Their commercial activity is mentioned by Arab geographers such as Ibn al-Faqīh, and according to these historical sources the Radhanites had four main trading routes: two maritime and two overland. In fact, this was an international network of Jewish merchants with trading ties all across the Islamic empire. Its agents were sent everywhere, from al-Andalus in the extreme west to China in the farthermost east. ${ }^{82}$

Jacoby, Trade, commodities and shipping in the medieval Mediterranean, Aldershot, Ashgate, 1997; David Jacoby, Commercial exchange across the Mediterranean: Byzantium, the Crusader Levant, Egypt and Italy, Aldershot, Ashgate, 2005;

Efraim Lev, 'Trade of medical substances in the medieval and Ottoman Levant (Bilad Al-Sham)', in Yaacov Lev (ed.), Towns and material culture, pp. $159-83$.

${ }^{78}$ Goitein pointed out some of these trading sources and directions in Mediterranean society, op. cit., note 14 above, vol. 1, pp. 153-4, 209-24.

${ }^{79}$ Efraim Lev, 'Trade of medical substances', op. cit., note 77 above.

\footnotetext{
${ }^{80}$ Zohar Amar and Efraim Lev, 'Economic aspects of the practical medical uses and commerce of medicinal substances by the member of the Jewish community of Cairo according to Genizah medical fragments' (forthcoming).

${ }^{81}$ al-Jāhiz, Kitāb al-Tabas bi-l-Tijāra, Cairo, 1935, pp. 25-34.

${ }^{82}$ Gil, Palestine, op. cit., note 14 above, vol. 1, pp. 611-30; Moshe Gil, 'The Radhanite merchants and the land of Radhan', J. Econ. Soc. Hist. Orient, 1974, 17: 299-328; Menahem Ben-Sasson, The emergence of the local Jewish community in the Muslim world: Qayrawan, 800-1057, Jerusalem, Magnes Press, 1996, pp. 76-7 (in Hebrew).
} 


\section{Efraim Lev and Zohar Amar}

A remarkable conclusion that emerges from perusal of the complete Levantine list is that at least some substances (cloves, cassia, purging cassia, sugar, rhubarb, mace, musk) were introduced to the Middle East, and later to Europe, by the Muslims. ${ }^{83}$ This may be considered as significant evidence of the contribution of the Muslims to pharmacy and medicine in general, and to the enrichment of the classical inventory of materia medica in particular. ${ }^{84}$ It is interesting, though, that trade in several of the above-mentioned substances was in the hands of members of the Jewish community of medieval Cairo, who traded with India, Sicily, Syria, North Africa, and other ports and cities. ${ }^{85}$

${ }^{83}$ Lev, Medicinal substances of the medieval Levant, op. cit., note 57 above, pp. 35, 289.

${ }^{84}$ M Rogers, 'The Arab contribution to botany and pharmacology', Arab Affairs, 1988, 6: 71-86.
${ }^{85}$ Goitein, Mediterranean society, op. cit., note 14 above, vol. 1, pp. 148-56, 209-24; Isaacs and Baker, op. cit., note 15 above, p. xi; Dietrich, op. cit., note 15 above. 